\title{
Determinants of Interest Rate Spread of Commercial Banks in Kenya
}

\author{
Boniface Kimondo Njeri ${ }^{1}$, Dr. Kepha Ombui ${ }^{2}$, Dr. Assumptah W Kagiri ${ }^{3}$ \\ ${ }^{1}$ MBA Student- Jomo Kenyatta University of Agriculture and Technology \\ ${ }^{2,3}$ Lecturer- Jomo Kenyatta University of Agriculture and Technology
}

\begin{abstract}
This study sought to investigated the determinants of interest rate spreads in commercial banks of Kenya based on data analysis and quantified the impact of those factors on interest rate spreads. Despite the liberalization of the financial sector, high interest rate spreads is still an issue of concern in a number of African countries, including Kenya. The project involved conducting an intensive study of the banking industry in Kenya. Various aspects contributing to bank interest rate spreads in the banking industry were explored. The research involved collecting data from commercial banks in Kenya, CBK, financial journals and newspapers. The target population was 1036 credit officers. The sample size was 103. Stratified random sampling was used. Questionnaires were used to collect primary data where drop and pick method was used. The data was processed using statistical package for social sciences (SPSS) to get various statistical measures such as the mean, frequencies and standard deviation which were applied in various processes which included validation, sorting, summarizing and aggregation of data. The data collected was analyzed using inferential statistics and descriptive statistics which involved frequencies and mean. The inferential statistics involved the use of Pearson's correlation and regression analysis. The results obtained helped to infer the determinants of interest rate spread in commercial banks of Kenya. Results indicated that all the variables of the study: Inflation rate, return on average assets, liquidity risk and credit risk influences interest rates spreads of commercial banks in Kenya. This was evidenced by the responses from respondents in regards to the study variables. The study concluded that indeed inflation rate, credit risk, liquidity ratio and returns on average assets influences interest rates spreads in commercial banks of Kenya by a substantial extent. It was recommended that a similar study should be done in Kenya. Further studies should also be carried out on operation cost and financial performance of commercial banks in Kenya with an aim of finding out their effect on interest rates spreads of the commercial banks.
\end{abstract}

Keywords: Credit Risk, Inflation Rate, Liquidity Ratio, Return on Average Assets

\section{Introduction}

Interest rate spread (IRS) can be simplistically defined as the difference between the interest rate charged on the borrowers and the rate paid to the depositors (Were \& Wambua, 2014). Spread is different from the rates because they are determined by the individual financial institutions (Mlachila, 2005). High interest rate spreads in commercial banks is an emerging policy issue in Kenya due to the significant role played by banks in the growth of the economy. As such, as the financial sector continues to enjoy financial liberalization and deepening, interest rate spreads are expected to narrow (Were \& Wambua, 2014). Financial sector liberalization enhances competition and efficiency among the players in the financial sector.

High interest rate spreads could be a reflection of a low level of financial sector development or inefficiency (Folawewol $\&$ Tennant, 2008). Despite the structural adjustment reforms leading to liberalization undertaken by many countries in sub Saharan Africa, high interest rate spreads continue to face these countries. Information to do with the efficiency of financial intermediation, monetary policy impact and profitability of the banks, influence the interest rate spread (Were \& Wambua, 2014).

Liberalization of the financial market in Kenya was realized in 1990s creating an environment of market-determined rates. However, high interest rate spreads have continued to persist attracting a lot of debate in both public and policy forums (Were \& Wambua, 2014). The role of the financial sector in facilitating economic growth is very critical and widely acknowledged in Kenya. The banking sector plays a dominant role in Kenya's financial sector. This is emphatic in the area of savings mobilization and provision of credit to investors (Folawewal and Tenant, 2008).

The development of the financial sector is an important contributor to economic growth development (Afanasieff et al., 2006). Lack of real growth in the developing countries has been associated with repressed financial sector necessitating them to adopt liberalization policies in order to spur economic growth and development (Folawewol \& Tennant, 2008). Financial liberalization entails the removal of repressive financial sector policies such as fixed interest rate and credit rationing deepen the financial sector opening it to competition, thus leading to competitive deposit and lending rates paving the way for the development of the financial sector and ultimately economic growth. Commercial banks are thus vital in the development of financial sector in the sense that they promote economic efficiency through financial intermediation (Tarus et al., 2012).

Interest rates are major economic factors that influence the economic growth in a country. It is one of the tools used by CBK to control inflation and to boost economic development (Corb, 2012). Control of inflation and deflation is one of the key functions of CBK and a mandate by the government. The rationale behind the need to control interest rates charged on credit or any other financial instrument is based on the need to control economic patterns that are seen to have great effects on the society. (Giovanni ,2006) found out that high interest rates set by 


\section{International Journal of Science and Research (IJSR) \\ ISSN (Online): 2319-7064}

Index Copernicus Value (2013): 6.14 | Impact Factor (2014): 5.611

central bank means that other financial institutions will have to charge high rates on their financial facilities since their main aim is to make profit.

\subsection{Statement of the Problem}

In Kenya, high interest rates raise the cost of credit restricting the access of potential borrowers to credit markets thus reducing investments and limiting growth potential of the economy (Were \& Wambua, 2014). Problems become more acute for small business, household enterprises and rural industries which are vital to promote equitable growth and reducing poverty in low income countries. Commercial banks discourage potential savers due to low returns on deposits and thus limits financing for potential borrowers, this is due to banks tendency of maximizing profits and thus widening the interest rate spreads. This study therefore seeks to find out the determinants of interest rates spread in commercial banks of Kenya.

\subsection{Objectives of the study}

\subsubsection{General objective}

The general objective of the study was to investigate the determinants of interest rate spread of commercial banks in Kenya.

\subsubsection{Specific objective}

The specific objectives of the study were:

1. To determine how inflation rate influence interest rate spread of commercial banks in Kenya.

2. To establish the influence of credit risk on interest rate spread of commercial banks in Kenya.

3. To find out how liquidity ratio influence interest rate spread of commercial banks in Kenya.

4. To determine the effects of return on average assets on interest rate spread of commercial banks in Kenya.

\section{Literature Review}

According to Tarus et al., (2012), individual bank-specific factors include operating or administrative costs, nonperforming loans, return on assets, and structure of the balance sheet, non-interest income, and bank size and bank liquidity. Factors specific to banking sector include degree of competition or market concentration, regulatory requirements such as statutory reserve requirements or the regulated minimum deposit rates. Macroeconomic indicators are the extraneous factors prevailing in the economy and include the real GDP growth rate and the inflation rate.

Ndung'u and Ngugi (2006) considered deposits, loans, Treasury bill rate and interbank rate. They established that spread is positively related to deposits but negatively related with loans. They integrated excess liquidity and nonperforming loans ratio as explanatory variables and established that a rise in NPLs ratio leads to a rise in spread while excess liquidity is negatively related with spreads. They undertook their studies at a macro level, majorly focusing on the macro-industry level variables, but both studies did not factor macroeconomic indicators such as inflation and GDP.
Were and Wambua (2014) investigation of the factors that drive interest rates in Kenya, considered not only the macroeconomic factors but also bank specific factors such as bank size, operative costs. They found out that there were some unobserved factors that are associated with IRS across banks. These factors could be related to the quality of management, management style, and differences in skills of the workforce, among others.

Mannasoo (2012) investigates the role of recent global financial crisis on interest spreads in Estonia. The pure spread is explained by the degree of bank risk aversion and the market structure of the banking sector. The volatility of money market interest rates is found to have a long -run impact on the spread. Other factors that drive the interest margins are the regulatory variables, efficiency of banks and bank portfolio effects. Credit risk was found to play a minimal role while higher bank liquidity was associated with lower interest margin.

A similar study by Siddiqui (2012) on individual specific data for a panel of 22 banks concludes that administrative costs, non-performing loans ratio and return on assets significantly influence interest spreads in Pakistan.

Ahokpossi (2013) did a more recent study on the determinants of interest margins in SSA using a sample of 456 banks in 41 SSA countries. The result established that whereas bank specific factors such as credit risk, liquidity risk and bank equity are vital, interest rate spreads are not sensitive to economic growth

\section{Research Methodology}

The study applied descriptive research design which describes data and characteristics about the population or phenomenon being studied. According to Mugenda and Mugenda (2003), descriptive research is the process of collecting information with the objectives of describing a phenomenon. The study adopted descriptive research design since it was applicable to enable the researcher to study phenomenon of interest rate spreads without manipulation of variables. It ensured complete description of the situation, making sure that there was minimum bias in the collection of data and enabling to reduce errors in interpreting data collected. According to Coopers and Schinder (2011) descriptive studies are more formalized and typically with clearly stated hypothesis and investigation questions.

The target population for the study was credit officers of commercial banks in Kenya. According to 2009 Central bank of Kenya survey, there are 43 commercial banks. The credit officers in the selected banks acted as units of analysis while the selected commercial banks were units of observation. Four banks were selected for the study.

Data obtained from primary data was analyzed using statistical methods. Both qualitative analysis and regression analysis were used as data analysis techniques. The results obtained from the analysis were presented in tables. Descriptive statistics was also used to summarize quantitative data which included mean, ANOVA, standard deviation and frequencies. Multiple regression analysis was then applied to find out the relationship of the determinants 


\section{International Journal of Science and Research (IJSR) \\ ISSN (Online): 2319-7064 \\ Index Copernicus Value (2013): 6.14 | Impact Factor (2014): 5.611}

of interest rates spread in Kenya commercial banks. The empirical model for the study was specified as follows: $y_{i}=$ $\beta_{1} x_{i j}+\beta_{2} x_{i 2}+\beta_{3} x_{i 3}+\beta_{4} x_{i 4}+\varepsilon_{I}$ where $\mathbf{y}_{\mathbf{i}}$ is the dependent variable (interest rate spread), $\mathbf{x}_{\mathbf{i j}}$ is the $i$ th observation on the $j$ th independent variable, $\beta$ is the regression intercept, $\boldsymbol{\varepsilon}_{\mathbf{i}}$ is the error in the $i$ th observation. $y_{i}$ Interest rate spread, $x_{i l}$ Credit risk, $x_{i 2}$ Liquidity risk, $x_{i 3}$ Return on average assets, $x_{i 4}$ Inflation rate $\varepsilon_{i}$ Error Term.

\section{Findings and Discussion}

All variable items were measured on a five point LikertType scale ranging from 1 being "Strongly Disagree" to 5 being "Strongly Agree", the means and standard deviations for each variable were recorded.

\subsection{Credit Risk}

Means of between $2.0789-4.3750$ and standard deviations of between $0.15172-0.95239$ were registered. The study findings therefore revealed that majority of the respondents agreed that the ratio of total bank loans to total assets influences interest rates spreads for a great extent (4.3750). They further agreed that credit risk analysis is vital for determining interest rates on loans (4.0500). However, it was clear that the research found that the ratio of nonperforming loans to total loan in commercial banks influences interest rate spreads to a small extent (2.0789). This is in line with Ahokpossi (2013) findings who established that credit risk influences interest rate spread. This finding also concurs with those of Hawtrey and Liang (2008), who investigated the effect of credit risk on interest rates spread and found credit risk to be a main determinant of interest rates spread.

\subsection{Inflation Rate}

The study findings revealed that majority of the respondents agreed that inflation rates influences interbank and inter branch lending rates to a great extent (4.5879). They further agreed that inflation rate adversely influences banks' lending rates to a great extent (4.3750). However, it was clear from the research findings that majority of the respondents were of the opinion that the inflation rates influences interest rates on deposits (4.0500). The question whether inflation rate influences banks' lending ability to the economic development projects was also supported by a great extent which had a mean of 4.2250. Inflation rate influences demand for bank loans to borrower was also supported with a mean of 4.1750. The findings are similar to those of Were and Wambua (2013), who revealed that inflation rate highly influences interest rates spread. Tarus et al (2012) in his study on determinants of interest rates found out that one of the key determinants of interest rates spread was inflation rate and other macroeconomic factors. His findings were similar to those got from this study.

\subsection{Liquidity Risk}

The study findings revealed that majority of the respondents agreed that liquidity risk adversely raises banks' lending rates to a great extent (3.9706). They further agreed that liquidity risk influences banks' ability to lend to a moderate extent (3.8676). However, it was clear from the research findings that majority of the respondents were of the opinion that change in liquidity risk causes change in deposit interest rates (3.7353). These findings were similar to those of Were and Wambua (2013) on the investigation of factors that drive interest rates in Kenya among them being liquidity ratio. However, Ndungu and Ngugi (2006) integrated excess liquidity and non-performing loans ratio and established that a rise in NPLs ratio leads to a rise in spread while excess liquidity is negatively related to interest rates spreads.

\subsection{Return on Average Assets}

The study findings revealed that majority of the respondents agreed that banks with big loan books have high return on average assets (3.8676). They further agreed that return on average assets influences banks' lending rates and also banks with high return on average assets offer lower interest rates on loans (3.7794). However, it was clear from the research finding that return on average assets influences deposit rate for investors to a small extent (2.4559). The findings concurred with those of Munjeri and Younus, (2009) who found out that bank with high return on average assets have high spreads as their assets are expected to be charging higher rates in order to have high returns. These studies are also similar to Ahokpossi (2013) findings in his study on determinants of interest rates spread; he found out that return on average assets plays a key role in interest rates determination. However, the result contradicts Europeans banks findings by Merceica et al (2007) of inverse relationship between interest rate spread and profitability.

\subsection{Interest Rate Spread}

The study findings revealed that majority of the respondents agreed that inflation rate influences interests rates spread in commercial banks to a great extent (3.9974). The respondents further agreed that bank credit risk has an impact on interest rates spreads of commercial banks (3.7647). On the contrary, it was clear from the research findings that majority of the respondents were of the opinion that bank credit risk has an impact on interest rates spreads of commercial banks (2.2118). Other studies that had similar findings on determinants of interest rates spread are provided by Hawtrey and Liang (2008) who investigated bank interest rates margins and found out that cost efficiency, risk aversion, and interest rates volatility to be among the main determinants of interest rates spreads. Were and Wambua (2014) in their study also found out that macroeconomic factors and bank specific factors play a great role in determination of interest rates spreads, these factors include inflation, liquidity ratio, return on average assets and credit risk. However according to (Folawewol and Tennant, 2008; Beck and Hesse, 2006), they established that IRS is influenced by the magnitude of the crowding effect of government borrowing, public sector deficits, inflation level of money supply reserve requirement and population size.

The results of the regression equation showed that, for a 1point increase in the independent variables, interest rate spread is predicted to increase by 0.864 , given that all the other factors are held constant. The model had a standard

\section{Volume 4 Issue 11, November 2015}




\section{International Journal of Science and Research (IJSR) \\ ISSN (Online): 2319-7064 \\ Index Copernicus Value (2013): 6.14 | Impact Factor (2014): 5.611}

error estimate of 0.73 . The equation for the regression model is expressed as: $Y=a+\beta_{1} X_{1}+\beta_{2} X_{2}+\beta_{3} X_{3}+\varepsilon_{i}$

$\mathrm{Y}=0.864+0.40 \mathrm{X}_{1}+0.402 \mathrm{X}_{2}+0.353 \mathrm{X}_{3}+0.472 \mathrm{X}_{4}+0.730$

Where: $\beta$ is a correlation coefficient

$\mathrm{Y}=$ Interest rate spread, $\mathrm{X}_{1}=$ Credit risk, $\mathrm{X}_{2}=$ Inflation rate,

$\mathrm{X}_{3}=$ Liquidity risk,

$\mathrm{X}_{4}=$ Return on average assets, $\varepsilon_{i}=$ Error term

The study therefore established that credit risk, inflation rate, liquidity risk and return on average assets significantly influence the interest rate spread in commercial banks of Kenya. All the variables were therefore significant. This means that all these were factors that had a notable influence in the interest rate spread of commercial banks in Kenya. However there are other factors other than the ones examined in the study that constitutes the remaining $36.8 \%$ which could not be explained by the study.

\section{Conclusion}

The study concludes that there is a positive linear relationship between interest rate spread and the determinants under study. The study establishes that interest rate spreads in Kenya has been on the rise though there are periods that they have declined. In general, the study found that all determinants are statistically significant in determining interest rate spreads. The significance of these variables thus suggests that they have an impact on interest rate spreads. All the independent variables under study were established to play an important and a key role in determining the interest rate spread in Kenya's banking sector.

\section{Recommendation}

As the research objectives stated, this study sought to find out determinants of interest rate spread among commercial banks in Kenya with regards to, credit risk, inflation rate, liquidity risk and return on average assets. However, the research did not exhaust everything and therefore suggests that: A similar study should also be carried out on the effect of interest rate spread on financial performance of commercial banks in Kenya incorporating more financial and accounting variables and also taking into account the prevailing macroeconomic situation in the country as opposed to the current study which took into consideration of only four interest rate spread variables.

\section{References}

[1] Aboagye, A. Q., Akoena, S. K., Antwi-Asare , T. O., \& Gockel, A. F. (2008). Explaining Interest Rate Spreads in Ghana. African Development Review.

[2] Afanasieff, T. S., Lhacer, P. M., \& Nakane, M. I. (2002). The Determinants of Bank Interest Spreads in Brazil. Banco Central do Brasil

[3] Ahokpossi, C. (2013). Determinants of Bank Interest Margins in Sub-Saharan Africa. IMF Working Paper.

[4] Bandaranayake, S. U. (2008). Issues Relating to Interest Rate Spread in Commercial Banking System of Sri Lanka. Sri Lanka: Department of Commerce \& Finance.

[5] Beck, T., \& Hesse, H. (2006, October). Bank Efficiency, Ownership and Market Structure: Why Are Interest Spreads
So High in Uganda? World Bank Policy. Research Working Paper.

[6] Brock, P., \& Franken, H. (2003). Measuring the Determinants of Average and Marginal Bank Interest Rate Spreads in Chile, Working Papers UWEC.

[7] Chirwa, E. W. (2001). Market Structure, Liberalization and Performance in the Malawian Banking Industry. African Economic Research Consortium (AERC).

[8] Chirwa, E. W., \& Mlachila, M. (2004). Financial reforms and interest rate spreads in the commercial banking system in Malawi. IMF Staff Pap.

[9] Folawewol, A. O., \& Tennant, D. (2008). Determinants of interest rate spread in sub-Saharan African countries: a dynamic panel analysis. A Paper Pre-pared for the 13th Annual African Econometrics Society Conference, 9-11July, Pretoria, Republic of South Africa.

[10] Gambacorta, L. (2004). How Banks Set Interest Rates? National Bureau of Eco-nomic Research Working Paper.

[11] Grenade, K. H. (2007). Determinants of Commercial Banks Interest Rate Spreads: Some Empirical Evidence from the Eastern Caribbean Currency Union. Eastern Caribbean Central Bank Staff Research Paper.

[12] Haruna, M. A. (2011). Empirical Analysis of Interest Rate Spread in Nigeria: Post Liberalization Period. International Journal of Social Sciences and Humanities Review.

[13] Jayaraman, T., \& Sharma, R. (2003). Determinants of Interest Rate Spread in the Pacific Island Countries: Some Evidence from Fiji. USPEC working paper.

[14] Mannasoo, K. (2012). Determinants of Bank Interest Spread in Estonia. EESTI-PANK Working Paper.

[15] Mugenda, O. M., \& Mugenda, A. G. (2003). Research Methods: Quantitative and Qualitative Approaches. Nairobi, Kenya: ACTS Press.

[16] Nachmias, F., \& Nachmias, D. (2007). Research Methods in the Social Sciences. London: Worth Publishers; 7th edition.

[17] Ndung'u, N., \& Ngugi, R. W. (2000). Banking Sector Interest Rate Spreads in Kenya.

[18] Ngugi, R. W. (2001). An Empirical Analysis of Interest Rate Spread in Kenya. African Economic Research Consortium (AERC).

[19] Perez, P. (2011). Determinants of Interest Rate Spreads in Belize. Belmopan: Central Bank of Belize. Publicationsresearch/conferences working paper.

[20] Samahiya, M., \& Kaakunga, E. (2012). Determinants of Commercial Banks' Interest Rate Spread in Namibia: An Econometric Exploration. Botswana Journal of Economics.

[21] Siddiqui, M. A. (2012). Towards determination of interest spread of commercial banks: empirical evidences from Pakistan.

[22] Tarus, D., Chekol, Y. B., \& Mutwol, M. (2012). Determinants of Net Interest Margins of Commercial Banks in Kenya. $A$ Panel Study. Procedia Economics and Finance.

[23] Were, M., \& Wambua, J. (2013). Assessing the determinants of interest rate spread of commercial banks in Kenya: An empirical investigation. Kenya Bankers Association.

[24] Were, M., \& Wambua, J. (2014). What factors drive interest rate spread of commercial banks? Empirical evidence from Kenya. Review of Development Finance.

[25] Brock, P. and H. Franken, 2002, "Bank Interest Margins Meet Interest Rate Spreads: How Good is Balance Sheet Data for Analyzing the Cost of Financial. Intermediation?"Central Bank of Chile.

[26] Mugenda, O.M. and Mugenda, A.G. (2003). Research Methods: Quantitative and Qualitative Research: Nairobi; Acts Press. 